\title{
Reform and Exploration of the Cultivation Model of Applied Undergraduate Talents
}

\author{
Zhao Zenghui, Tang Xuexue, Quan Jing, Su Guangxia, Yang Tao \\ School of Intelligence Science and Information Engineering \\ Xi'an Peihua University, Xi'an, China \\ 296883619@qq.com
}

\begin{abstract}
Applied undergraduate education is the inevitable result of the popularization of higher education and economic and social development. In the course of reforming the training model of applied undergraduate talents, there are some problems such as insufficient understanding of talents training, unreasonable curriculum construction and professional management, insufficient teaching staff, insufficient practical training, lack of practical equipment input and support, and professional setting of applied undergraduate universities does not well match with local economic development needs. Applied undergraduate talent training can start from adjusting teaching method, reforming teaching content, strengthening practical teaching and formulating corresponding talent training program and curriculum syllabus; then strengthen teacher construction, optimize capital structure, expand practical teaching, increase laboratory opening; and deepen curriculum reform and enhance scientific research and innovation ability; and at last cooperate with innovative talents training, carry out entrepreneurship education to serve local economy.
\end{abstract}

Keywords-Applied undergraduate; Talent training; Reform; Innovation

\section{INTRODUCTION}

With the popularization of higher education, colleges and universities have begun to diversify. The consensus of many local undergraduate colleges is to cultivate applied talents that are linked to local economic development. In October 2015, the Ministry of Education proposed that ordinary undergraduate colleges should change from "traditional research type" to "application type". This change is not only reflected in the adjustment of the orientation and mode of the school, but also in the talent training mode. The reform is of great significance for promoting applied undergraduate education. Under the new situation, it is imperative to explore the reform of the talent training mode of applied universities.

Many undergraduate colleges have a vague positioning on the reform of applied talent training mode. They have not yet established a perfect application-oriented talent training teaching system, and still use the traditional teaching methods of academic talent training, which will seriously affect the cultivation of applied talents. quality. How to comprehensively deepen the reform of the application-oriented talent training mode is the focus and difficulty of the current reform of the talent training mode of applied undergraduate colleges, and it is also a huge challenge that we are currently facing.

\section{CURRENT SITUATION AND EXISTING PROBLEMS OF THE TRAINING MODE OF APPLIED UNDERGRADUATE TALENTS}

\section{A. Insufficient understanding of talent cultivation}

The talent training objectives of applied undergraduate colleges are different when they are formulated. They are different from "application type" and "research type" universities, but they often appear "drift" in actual implementation. The reason is that although the talent training target of undergraduate colleges in many places is the cultivation of applied talents, the talent training program still refers to the training mode of "research-type" colleges and universities, overemphasizing the integrity of the theoretical system, and still applying the research-oriented talent training program. However, the practice application link is weakened; the students have not grasped enough of the theoretical knowledge points, and the practical hands-on ability is weak, and the final employment is not ideal. Local undergraduate colleges often only carry out simple administrative management and routine teaching management for the established majors. The writing and execution of the syllabus and the delivery of teaching tasks are all carried out and carried out for specific courses. The development of teaching work and the closeness of the profession are very weak. As a result, the construction and development of the profession has been severely constrained.

\section{B. Insufficient construction of teaching staff}

The construction of the teaching staff is the top priority for ensuring the quality of talents in applied universities and is the key to professional construction. The current general phenomenon is that teachers with different professional technical backgrounds teach the same course in the first year of the same department, and more teaching assistants have not played a role. Many graduate students who have just graduated have become the backbone teachers in the front line of teaching without any teaching and work experience. "Younger teachers" is a common feature of applied universities. Teachers who lack the background of engineering practice and innovative ability emphasize more theoretical teaching in teaching, which is inconsistent with the goal of talent training in applied undergraduate colleges: this not only affects the quality of teaching, but also makes students not equally enjoy teaching resources. In the classroom, there have been many 
phenomena such as reading PPT, reading textbooks, etc., which directly lead to the lack of good innovation in applied talent training. In many local undergraduate colleges, the phenomenon of heavy academic qualifications and light abilities is widespread, which not only hinders the introduction of skilled craftsmen, but also forces some front-line teachers with high teaching level and years of teaching experience to pursue high academic qualifications, while neglecting or no more. Focus on improving your practical ability. The phenomenon of the serious lack of "double-skilled" teachers in applied universities is not compatible with the undergraduate applied talents training objectives, and the strength of innovative entrepreneurial teachers is relatively weak. At present, most colleges and universities have insufficient teaching experience in innovative and entrepreneurial teachers and lack experience in entrepreneurial practice. Although some colleges and universities often invite entrepreneurs and successful entrepreneurs to hold a series of innovative and entrepreneurial lectures, due to the lack of sufficient time for students and lecturers to communicate, college students' innovation and entrepreneurship education is mostly flashy. In order to implement the innovation and entrepreneurship education, the school's innovation and entrepreneurship ability is the focus.

\section{Lack of training equipment input}

The training course plays a vital role in the overall education level of applied universities. Many applied undergraduate colleges have certain misunderstandings in the process of teaching transformation. The reform of practice links is not strong enough. The examination of students' comprehensive ability is only measured by the means of examination, and the practice has not undergone in-depth reform. In the field of practical training, there are few innovative training and comprehensive design, and the basic training content is the vast majority. The training content is outdated, and some hardware and software have already been eliminated, which is seriously out of touch with social production development. The training method is based on the middle school teaching mode. The training teacher prepares the training equipment and materials first. The students only need to operate directly according to the operation method set by the teacher. The consequence is that students lack comprehensive understanding and understanding of the training content, and there is no interest in active exploration; teachers lack objective evaluation of student training results. Applied colleges and universities have insufficient funds for training teaching equipment, resulting in backward training equipment and low per capita resource utilization. Applied undergraduate colleges need to pay attention to practical training, and also need to increase investment in training equipment. It is also necessary to provide students with an environment and conditions that can independently complete comprehensive design and innovative training. Only in this way can students improve their learning ability in the process of moving their brains, and they can lay the foundation for future career choices.

\section{Professional Settings do not match well with local economic development needs}

The professional management consciousness of local undergraduate colleges is relatively weak, the discipline professional setting does not match the local economic development needs, and the quality of talent training does not meet the social needs. Many applied undergraduate colleges have opened a large number of liberal arts majors, and the cultivated talents have poor adaptability to the society; professional settings are not very compatible with local economic development needs, resulting in many graduates not finding suitable positions for their own professions. It is very unfavorable to society, schools, students and parents, and it also causes a serious waste of investment in education. In addition, many undergraduate colleges are not flexible enough in terms of professional settings. The characteristics of different types of education are not shown, and the autonomy of school-running and professional setting is relatively weakened. The local government does not pay enough attention to the cooperation between schools and enterprises in the application of technical and technical talents. Most of the enterprises do not participate in the professional setting of the school, and the enthusiasm for running schools is not high. These have led to the lack of professional settings and local economic development. Very matching.

\section{REFORM AND EXPLORATION OF THE TRAINING MODE OF APPLIED UNDERGRADUATES}

\section{A. Based on the needs of research talents, clarify the target of applied talent training}

The training system for applied talents in colleges and universities can only be based on market demand, which can provide strong support for social and economic construction. At present, China's economic and social development has different knowledge structure and professional ability from applied talents. The main body has the following two points: First, large-scale industrialization and informationization have accelerated the technological upgrading and demand changes, and there is no solidity. The application-based skills of the theoretical foundation are difficult to adapt to the development and changes of professional positions. Therefore, the application-oriented talent training system should strengthen the cultivation of practical hands-on ability while still emphasizing the cultivation of a relatively solid technical theory foundation to adapt to rapid technological progress and market changes. Second, under the conditions of market economy, applied talents often assume multiple roles, rather than pure technical work. Therefore, the talent training system cannot emphasize professional technical education unilaterally, but also pay attention to the cultivation of multidisciplinary knowledge such as economy, management, and law. To adapt to the complex market environment and future development changes.

Therefore, we believe that high-quality applied undergraduates at this stage should have the following characteristics: First, master a solid foundation of natural theory and systematic subject knowledge; second, have strong 
engineering practice and related expertise. The comprehensive application ability; Thirdly, it has a certain sense of technological innovation and ability, can directly participate in enterprise line technology innovation, solve the engineering and technical problems faced by enterprises; Fourth, master the necessary multi-disciplinary knowledge of economy, management, law, etc. It can better deal with the economic, management and legal issues involved in technical activities. Fifth, it has a good ideological and moral quality, a healthy physical and psychological quality, and a strong lifelong learning ability.

\section{B. Adjust methods and reform contents}

Scientific adjustment of teaching methods and vigorous reform of teaching content is the key to realizing the cultivation of talents in applied undergraduate colleges. The goal of talent cultivation should be set according to the characteristics of applied talents. The formulation of teaching plans should correspond to the goal of talent training. Professional teaching content should fully consider the structural proportional relationship between knowledge, ability, quality, practice and market demand. When writing a talent training program, we should adhere to the practical ability training as the main line, aiming at cultivating applied talents, and strive to form characteristics and advantages in professional subject basic knowledge, practical training and cultural quality education, focusing on cultivating students' practical ability and Innovative ability; enrich teaching content, set up innovative and entrepreneurial courses, actively encourage students to carry out scientific innovation and entrepreneurship, participate in innovation and entrepreneurship competitions, cultivate students' innovative spirit and self-confidence, and achieve the purpose of applying what they have learned.

\section{Optimize teacher structure}

The application-oriented college teachers must adhere to the guiding ideology of both theoretical and practical teachers. The main body of the faculty should be a "double-type" teacher who can engage in both theoretical teaching and rich enterprise experience. "Double-teacher" teachers are more conducive to the cultivation of students, but also help teachers to conduct scientific research and carry out industry-university-research cooperation, which enables students to seamlessly connect with enterprises after graduation. In the long run, the application-oriented undergraduate adapts to the needs of the society and realizes the training goal of applied talents. More "double-type" teachers are needed. Schools should hire more professional and technical personnel with rich practical experience to practice teaching. task. Strengthen the construction of the "double-type" teacher team and optimize the teacher structure. The school and the enterprise respectively choose the subordinate superiority secondary college to jointly build with the industry. The dean of the secondary college is the person in charge of the cooperative enterprise, and the enterprise directly participates in the whole process of talent cultivation.

\section{Integration of industry and education, cooperation between university and enterprise}

The school and the enterprise cooperate in depth to build a professional curriculum system, build a double-skilled teaching team, build a practical training teacher base, and establish a cooperation platform for mutual benefit and mutual benefit between schools and enterprises to ensure that the applied undergraduate talent training model is steadily moving toward the established goals. . Schools can increase the guidance of students' extracurricular interest groups, challenge cups, and innovation competitions, and cultivate students' innovative spirit and practical ability. First of all, it is necessary to put a practical teaching system suitable for the training objectives of applied undergraduate talents in a prominent position, and secondly, to get out of the new line of applied undergraduate colleges. To strengthen the experimental innovation teaching, it is necessary to increase the laboratory, and it is possible to carry out school-enterprise joint construction, mutual benefit, and more cooperation between industry, university and research institute to ensure that the applied undergraduate talent training model is steadily advanced towards the established goal.

\section{E. Establish a suitable personnel training system}

In view of the characteristics of applied talent training, schools should explore various advanced teaching methods and deepen curriculum reform. The purpose of the class is to learn the knowledge. It is not necessarily limited to classroom teaching. Teachers can also teach students in the laboratory, training center or enterprise production site. They can also organize students to visit excellent business units and conduct holiday business internships. Wait. Teachers should make full use of modern information technology, use the three-dimensional teaching carrier of multiple media, establish online teaching platforms for each course, build online classrooms, conduct online exercises, answer questions, and achieve "all-weather teaching." In the construction of educational informatization, it is necessary to cultivate the ability of school teachers to use information technology. They can arrange irregular training for teachers and master the most advanced information technology. Teachers can combine teaching with information technology to develop new courses, such as micro-classes. This will not only deepen the curriculum reform, but also promote communication between teachers and students. The applied technology-based undergraduate talent training mode can be effectively promoted in Shaanxi and even the whole country. Each applied technology-based university can learn from the secondary training mode, combine the actual situation of each university, enhance the effectiveness of school service social development, and strengthen schools and industry enterprises. The degree of cooperation enhances the combination of the training process and student practice, and improves the matching between the quality of training and the needs of the industry.

Through the trial operation of this training mode, a training system that is more suitable for the training of talents in current applied technology universities is gradually explored. 
According to the system for personnel training, it is expected that within one to two years, the "two skins" of innovation and entrepreneurship education and professional education will be transformed into organic integration.

\section{F. Start a startup education to serve local economy}

Applied undergraduate colleges and universities should give full play to their own flexible advantages, standardize the construction of school-enterprise comprehensive practice bases, conduct research on school-enterprise collaborative innovation talents, and carry out a new line of production, education and research. The application disciplines for modern manufacturing and emerging industries are developing rapidly. The role of entrepreneurship education in applied undergraduate colleges is also very obvious. It is necessary to combine the reality of entrepreneurship education to build a sound teaching management system as soon as possible. Applied undergraduate colleges should be based on the talent needs of the local economy, and closely integrate disciplines and professional construction with local industries to better serve the local economy.

\section{CONCLUSION}

In the process of reforming the applied undergraduate talent training mode, there is insufficient understanding of talent training, curriculum construction and professional management are unreasonable, the teaching staff is insufficiently constructed, the training teaching is insufficient, the input and support of training equipment is lacking, and the application-oriented undergraduate college major The setting is not very compatible with local economic development needs. Application-oriented undergraduate talent training can start from adjusting teaching methods, reform teaching content, strengthen practical teaching and formulate appropriate personnel training programs and curriculum syllabus; strengthen teacher construction, optimize teacher structure, expand practical training, and increase experimentation Room opening efforts: deepen curriculum reform, enrich teaching methods, enhance scientific research and innovation capabilities; collaborative innovation talent training, carry out entrepreneurship education, and better serve the local economy.

Our goal is to explore the law of undergraduate applied talents with a solid theoretical foundation, strong practical application ability and certain innovative spirit through research and practice, and build a new scientific and rational engineering application undergraduate talent training system. It covers basic theory and professional knowledge curriculum system, practical ability training system and practical teaching hardware platform system.

\section{REFERENCES}

[1] Zhang Man. On the reform of talent training mode in applied undergraduate colleges under the background of education reform[J]. Journal of Anzao University of Technology(Social Science Edition), 2016,5(18):75-79. "(In Chinese)"

[2] Wang Lixia. The problems and suggestions in the professional construction of local applied undergraduate colleges[J]. Journal of Jilin Engineering and Technology Teachers College, 2015, 6(31): 36-39. “(In Chinese)"

[3] Zhou Zhaode, Li Dai, Basic Thinking on the Implementation of Applied Undergraduate Education[J]. Journal of Hainan Normal University (Natural Science Edition), 2017, 30(1): 108-113. "(In Chinese)"

[4] Hong Lu. Research on the Cultivation Strategy of Entrepreneurial Talents in Applied Undergraduate Universities[J]. Education and Teaching Forum, 2015(13): 203-204. "(In Chinese)"

[5] Wu Gongde, Wang Xiaoli. Reform Ideas of Talent Cultivation Model in Local Applied Undergraduate Colleges[J]. Education and Teaching Forum, 2016(1): 88-89. “(In Chinese)”

[6] Zhai Xiaoguang. Problems and Reform Paths of Talent Cultivation Mode in Private Applied Undergraduate Universities-Taking the Application of German Applied Undergraduate Talents as a Cognition[J].Journal of Zhejiang Shuren University(Humanities and Social Sciences),2018(05): 17-21. "(In Chinese)"

[7] Xu Zili, Li Jin, Qiao Yinhu, Zhang Chunyu, Zhang Kaibao, Zhang Cheng. Exploration of the training path of applied undergraduate talents under the background of new engineering [J]. Journal of Heilongjiang Institute of Technology(Comprehensive Edition),2018,18(09) :19-23. "(In Chinese)"

[8] Zhang Ling, Wu Limin, Zhang Ximei, Mi Long. Research on the Problems and Countermeasures of Applied Talents Training in Local Undergraduate Colleges [J]. Journal of Xingtai University, 2018,33(03): 189-190. "(In Chinese)"

[9] Li Xuecheng. Research on Examination Reform under the Training Objective of Applied Undergraduate Talents [J/OL]. Journal of Henan Institute of Education (Philosophy and Social Sciences): 1-4 [2018-10-02].https://doi. Org/10.13892/j.cnki.cn41-1093/i.2018.04.015. "(In Chinese)"

[10] Chen Dongsheng. Discussion on Talent Training Programs in Applied Undergraduate Colleges[J]. Textile and Apparel Education, 2018, 33(04): 267-271. "(In Chinese)" 